\title{
Recent patents in tissue engineering
}

\begin{tabular}{|c|c|}
\hline Patent \# & Subject \\
\hline EP 891783 & $\begin{array}{l}\text { A new device for bone tissue engineering comprises a scaffold material } \\
\text { consisting of a bioactive, osteoconductive and bone-bonding } \\
\text { segmented thermoplastic copolyester ether and cultured osteogenic } \\
\text { or osteoprogenitor cells. }\end{array}$ \\
\hline WO 9901538 & $\begin{array}{l}\text { The production of a tissue-engineered construct by providing a sub- } \\
\text { strate of biocompatible synthetic polymer for contact with mammalian } \\
\text { cells,for use in coronary bypasses, liver grafts, and delivery systems } \\
\text { of proteins or other molecules secreted by the cell constructs. }\end{array}$ \\
\hline US 5859150 & $\begin{array}{l}\text { A prepolymer for use in surgical devices, drug delivery matrices, } \\
\text { coatings, lubricants, etc., comprising an aliphatic polyoxaester } \\
\text { covalently linked to a polymerizable region. }\end{array}$ \\
\hline US 5855610 & $\begin{array}{l}\text { Cell-matrix structures for tissue-engineered tubes or valves in blood } \\
\text { vessels, intestines, or hearts; comprise a fibrous material of } \\
\text { biocompatible, biodegradable synthetic polymer seeded with } \\
\text { dissociated human cells that form a tissue structure following } \\
\text { implantation into a human or animal recipient. }\end{array}$ \\
\hline WO 9853768 & $\begin{array}{l}\text { Polymeric implant materials reinforced with fibers in parallel } \\
\text { orientation; they may be used in facilitating regeneration of load- } \\
\text { bearing tissues (e.g., articular cartilage and bone). }\end{array}$ \\
\hline WO 9852543 & $\begin{array}{l}\text { An injectable polymer suspension that forms an interpenetrating } \\
\text { polymer network in vivo; useful for tissue engineering, particularly } \\
\text { for joint resurfacing and plastic surgery, and for drug delivery. }\end{array}$ \\
\hline WO 9851408 & $\begin{array}{l}\text { Hydrogel composites formed by polymerizing unsaturated } \\
\text { monomers and multi-olefinic cross-linking agents in the presence of } \\
\text { a disintegrant; useful for controlled drug delivery and for making } \\
\text { devices for artificial pancreas, cornea, skin, or cartilage. }\end{array}$ \\
\hline
\end{tabular}

WO 9846286 A biodegradable polymer containing N-desaminotyrosyl-tyrosine O-phosphate units, used for drug and diagnostic delivery, medical implants, instruments, bone and nerve grafts, and dressings.

WO 9844027 A porous polymer material preparation made by forming pores by gas foaming and leaching out the particulate material to form additional porosity; useful in drug delivery or tissue engineering (e.g., as substrates for the formation of bone or for the treatment of periodontal disease).

WO 9843686 A new modified fibrin containing a bioactive factor, covalently bound to a protein network; useful in promoting cell growth, wound healing, and tissue regeneration, in tissue engineering (e.g., to create neovascular beds for cell transplantation), and as a surgical adhesive or sealant.

WO 9842356 In vitro elimination of tumor cells by labeling a cell population, recording its image, and directing a laser beam to individual labeled cells; used particularly to eliminate tumors from hematopoietic cells (specifically enriched in stem cells) intended for reintroduction into a patient (e.g., in the treatment of breast cancer).

WO 9825575 Treatment of anatomical defects in an animal, which comprises preparing a suspension of cells uniformly dispersed in a biodegradable, biocompatible hydrogel solution that is partially hardened, and implanting the suspension at the site of the defect, where the hydrogel solution fully hardens.

DE 19648876 A method for the preparation of a natural implant for human or anima body tissue consists of growing and/or differentiating suitable body cells on a cell underlay using a culture medium. The implants are used in tissue engineering (e.g., to repair broken bones).

WO 9812228 A new polymer made up of a polymeric backbone with a polysaccharide side chain, particularly modified alginate bonded to the molecule, used for tissue engineering and the repair or replacement of bone and soft tissue, including dental applications, relining of joints, and alteration of facial features.

\section{Assignee}

Author

Date Status

sotis (Bilthoven,

The Netherlands)

Bovell YP, de Bruijn JD, 1/20/99 A1

van Blitterswijk CA,

van den Brink J

MIT

(Cambridge, MA)

Gao J, Langer RS,

$1 / 14 / 99 \quad A 1$

Niklason LE

Ethicon Inc.

(Somerville, NJ)

Bezwadar S,

$1 / 12 / 99 \quad A$

Children's Medical

Center

(Cambridge, MA) BE, Shinoka T,
Vacanti JP

$1 / 5 / 99 \quad A$

OsteoBiologics Inc. (San Antonio, TX)

Kieswetter K, Leather-

$12 / 3 / 98 \quad A 1$ bury NC, Niederauer GG, Slivka MA

General Hospital Corp.; MIT Anseth K, Elisseeff JH, 11/26/98 A1 (Cambridge, MA); Univ. Technology Corp.

Park K

Park K

11/19/98 A1

Johns Hopkins

Leong KW, Mao H

10/22/98 A1

Univ. School of Med.

(Baltimore, MD)

Univ. Michigan

(Ann Arbor, MI)

Harris L, Mooney DJ,

10/8/98 A1 Shea $L$

Hubbell J, Schense JC

10/8/98 A1

California Inst

Technology

(Pasadena, CA)

Palsson BO

Palsson BO

10/1/98 A1

Children's Medical Atala A, Borland KM, Center; Reprogenesis Nelson GP, Zhou T Inc. (Cambridge, MA)

Minuth W

Minuth W

$5 / 28 / 98 \quad A 1$

Univ. Michigan

Bouhadir KH,

$3 / 26 / 98 \quad A 1$
6/18/98 A2
Mooney DJ, Rowley

JA, Wong WH 